\title{
Examining Graduate Students' Philosophies of Education: An Exploratory Study
}

\section{Mary Katherine Watson, Georgia Institute of Technology}

Mary Katherine Watson is a PhD candidate in Civil and Environmental Engineering (CEE) at Georgia Tech (GT). Through support from a National Science Foundation Graduate Research Fellowship, she has been working to improve the quality of sustainability education in CEE at GT through development and application of a variety of assessment tools and educational interventions. In addition to research in the field of engineering education, Mary Katherine is the founding president of the GT chapter of the American Society for Engineering Education (ASEE). Also at GT, Mary Katherine completed an MS in Environmental Engineering with research focused on biological treatment of organic surfactants. Prior to enrolling at GT, she received BS and MS degrees in Biosystems Engineering from Clemson University.

\section{Ms. Alexandra Emelina Coso, Georgia Institute of Technology}

Alexandra Coso is a Ph.D. Candidate in the Cognitive Engineering Center at Georgia Tech, where she is pursuing a doctorate in aerospace engineering. She received her B.S. in aerospace engineering from MIT and her M.S. in systems engineering from the University of Virginia. Alexandra is actively involved in the ASEE Student Division and the Graduate Engineering Education Consortium for Students, and she co-founded a Georgia Tech ASEE Student Chapter in the fall of 2011. Her research interests include the integration of stakeholders into the engineering design process, development and evaluation of interdisciplinary engineering courses and programs, mixed methods research designs, and graduate student experiences in engineering programs. 


\title{
Examining Graduate Students' Philosophies of Education: An Exploratory Study
}

\begin{abstract}
As graduate students become faculty members, their thoughts about the role of education and design of learning environments will significantly impact students' quality of education and the caliber of practicing engineers in the future. Thus, a study was conducted to determine and analyze graduate students' philosophies of education to provide insights into the instructional practices that will soon dominate engineering education. Students enrolled in graduate programs at the Georgia Institute of Technology within a variety of engineering and non-engineering disciplines were recruited to participate. Students completed an amended, online version of the Educational Philosophy Inventory, which is a theoretically-grounded instrument that allows for classification of respondents' views into one of the five major educational philosophies: essentialism, perennialism, progressivism, social reconstructionism, or existentialism. Responses to supplementary questions allowed for students' philosophies to be compared based on discipline, gender, past educational experiences, current teaching practices, and future career goals. Students' philosophies were also characterized as espoused or enacted by comparing their self-declared philosophy with that determined by the Inventory. Results indicated that essentialism is the predominant philosophy among the graduate students in this sample, according to both the Educational Philosophies Inventory and student self-reflections. Students' current teaching practices, as well as their ideal future teaching methods, are characteristic of essentialism and perennialism, two philosophies that were commonly demonstrated for them during their undergraduate and graduate careers. Several discrepancies between Inventory results and student self-reflections support the need for educational interventions to inform graduate students (i.e. future instructors) about educational philosophies and their implications for teaching and learning.
\end{abstract}

\section{Motivation}

Today's graduate students represent the next generation of faculty. This particular generation of graduate students has participated in a variety of teaching styles and interventions, from lecturebased classes to problem-based learning and technology-centered instruction. As they enter classrooms as instructors, they may choose to adopt one or more of these methods or derive their own. Research has shown that an instructor's educational philosophy can affect his or her approach to instruction ${ }^{1,2,3}$. In most cases, an instructor is unaware of his or her philosophy, as it is embedded in their approach to course design and their daily interactions with students ${ }^{4}$. Yet, research illustrates that one's philosophy, or conceptions about education (teaching and learning), is influenced by his or her prior experiences, discipline, and training in educationrelated courses ${ }^{1,5,6,7}$. While studies in this area have focused mostly on the perceptions of faculty when examining teaching approaches and philosophies ${ }^{6}$ or doctoral students in non-engineering departments $^{1,8}$, there is a need to more closely examine graduate students' philosophies, specifically in engineering disciplines ${ }^{7}$. 


\section{Previous Research}

\section{Philosophy of Education}

Conceptions of teaching and learning have been examined by a variety of scholars. These conceptions, beliefs, perspectives, and philosophies describe the "understanding, thinking and beliefs about teaching and learning that can potentially influence teaching actions ${ }^{8}$." Authors have defined the different conceptions on a continuum from instructor-centered to learnercentered $^{1,8,9}$. At the most extreme, the instructor is the central figure in the course and his or her role is to transmit course content to students. The opposite end of the continuum describes students as the agents of their own learning and instructors as facilitators during this process. Different categorizations of conceptions along this continuum have been defined in the literature $e^{4,8,9,10}$. For this research, five contemporary philosophies of education will be used to capture differences in conceptions of teaching and learning ${ }^{9,10}$. Two are instructor-centered, while the other three are learner-centered philosophies (See Table 1).

Table 1. Comparison of philosophies of education, including differences in focus of study instructor role (Adapted from $\mathrm{Koch}^{11}$ ).

\begin{tabular}{|lll|}
\hline Philosophy & Focus of Study & Role of Instructor \\
\hline $\begin{array}{l}\text { Perennialism } \\
\text { Instructor-Centered) }\end{array}$ & $\begin{array}{l}\text { Enduring ideas found in the great } \\
\text { works of the field. }\end{array}$ & $\begin{array}{l}\text { Instructors dialogue with } \\
\text { students to reason about the } \\
\text { great ideas. }\end{array}$ \\
\hline $\begin{array}{l}\text { Essentialism } \\
\text { (Instructor-Centered) }\end{array}$ & $\begin{array}{l}\text { Core knowledge that students need } \\
\text { to be educated citizens; this } \\
\text { knowledge is embodied in } \\
\text { traditional disciplines. }\end{array}$ & $\begin{array}{l}\text { Instructors are the central } \\
\text { figures in the classroom, } \\
\text { transferring their knowledge } \\
\text { to students. }\end{array}$ \\
\hline $\begin{array}{l}\text { Progressivism } \\
\text { (Student-Centered) }\end{array}$ & $\begin{array}{l}\text { Integration of study with real-life } \\
\text { experiences through active } \\
\text { learning, problem solving, and } \\
\text { experimentation. }\end{array}$ & $\begin{array}{l}\text { Instructors structure the } \\
\text { learning activities and } \\
\text { encourage students to explore } \\
\text { the ideas that arise. }\end{array}$ \\
\hline $\begin{array}{l}\text { Social Reconstructionism } \\
\text { (Student-Centered) }\end{array}$ & $\begin{array}{l}\text { Schooling promotes social and } \\
\text { political reform by focusing on } \\
\text { social problems and the need for } \\
\text { change. }\end{array}$ & $\begin{array}{l}\text { Instructors guide students to } \\
\text { think critically about social } \\
\text { injustice and challenge } \\
\text { oppression. }\end{array}$ \\
\hline $\begin{array}{l}\text { Existentialism } \\
\text { (Student-Centered) }\end{array}$ & $\begin{array}{l}\text { Students choose their own course } \\
\text { of study in an effort to figure out } \\
\text { their place in the world. }\end{array}$ & $\begin{array}{l}\text { Instructors support students } \\
\text { in exploring their own } \\
\text { interests. }\end{array}$ \\
\hline
\end{tabular}

Two of the philosophies, perennialism and essentialism, promote classrooms where content and skills are transmitted from instructors to students (teacher-centered classrooms). Perennialists advocate that instructors should dialogue with students to convey timeless knowledge from seminal works in the field. Essentialists propose that instructors should cover fundamental concepts and educate students to become functional members of society. The other three philosophies, progressivism, social reconstructionism, and existentialism, address students' needs 
and interests while preparing them to succeed in an evolving society. Progressivists design learning activities and environments to encourage students to learn through authentic experiences. Social reconstructivists prompt students to critically examine modern social dilemmas, while existentialists encourage students to tailor their educational journey to develop their own goals and interests. Overall, each of the major philosophies of education supports learning environments with different focuses of study and instructor roles ${ }^{9,10,11}$.

\section{Possible Factors Affecting Philosophies of Education}

Research has shown that an instructor's educational philosophy can affect his or her approach to instruction ${ }^{2,3}$. In addition, one's philosophy, or conceptions about education (teaching and learning), is influenced by one's prior experiences ${ }^{5,6,7}$. While studies have focused on the perceptions of faculty when examining teaching approaches and philosophies ${ }^{6}$, there is a need to more closely examine graduate students' philosophies ${ }^{7,8}$.

When considering different factors which could influence an individual's philosophy of education, research has indicated that faculty members' approaches to education within engineering are influenced by their experiences as students ${ }^{6}$. Studies have specifically described faculty members' perceptions of teaching and learning as anchored in their undergraduate experiences, while others have suggested students' experiences in graduate school do not affect their perceptions ${ }^{7}$. Yet, none of the studies have compared the graduate and undergraduate experiences to an individual's own philosophy to confirm the effect of previous educational experiences.

Unlike secondary and primary schools teachers, many faculty members have never participated in a formal teaching and learning course ${ }^{1}$. This raises the question of whether developing knowledge about how students learn and different learning techniques affects one's philosophy of education. In one study, Saroyan and colleagues ${ }^{8}$ examined doctoral students' conceptions of teaching and learning using an open-ended questionnaire distributed before and after a course on teaching and learning. The results indicated that the students in the sample began with more instructor-centered conceptions of education and, following the completion of the course, held more learner-centered conceptions ${ }^{8}$. The scope of the study, however, focused only on students who self-selected to enroll in a teaching and learning course and did not include graduate engineering students. Still the findings from Saroyan and colleagues' research ${ }^{8}$ demonstrate the importance of including training in course instruction as a factor when examining an individual's philosophy of education.

Research about faculty members has also indicated that differences in disciplinary affiliation can affect an individual's educational philosophy ${ }^{3,4}$. For example, instructors in engineering disciplines more commonly hold instructor-centered perspectives ${ }^{3,6}$. Science disciplines have also been known to embrace instructor-centered perspectives ${ }^{3,4}$. In one study, secondary education teachers-in-training were examined to empirically determine if their perspectives on 
teaching differed due to their disciplinary majors ${ }^{4}$. This research indicated that individuals with backgrounds in the sciences were more likely to hold a transmission, instructor-centered approach to teaching than individuals with backgrounds in business or the arts ${ }^{4}$. Based on these studies, it is evident that empirical research with a specific focus on higher education settings and the inclusion of engineering students is necessary to gain insight into the differences in educational philosophies of these different disciplinary groups.

\section{Research Questions}

There are many studies related to educating graduate students about the scholarship of teaching and learning ${ }^{12,13,14}$. Overall, however, research on the beliefs and experiences of graduate students ${ }^{15}$, particularly in engineering, is limited ${ }^{15}$. The few studies about graduate students' perceptions of teaching and learning have either focused on only non-engineering doctoral students $^{8}$ or only engineering doctoral students ${ }^{7}$. Future research needs to include both groups, as well as examine how the previous experiences, specifically the undergraduate years ${ }^{5}$, affect students' philosophies of education.

To more closely examine graduate students' philosophies, several research questions have been identified for this study:

(1) Which philosophies of education predominate among graduate students?

(2) How do graduate students' previous educational experiences relate to their philosophies of education?

(3) Are graduate students' philosophies of education reflected in their current teaching practices?

(4) What do graduate student philosophies of education suggest about the future of engineering education?

\section{Methods}

\section{Survey Development}

A survey was developed based on the Educational Philosophy Inventory, which is a theoretically-grounded survey used widely in primary and secondary education ${ }^{9}$. The instrument allows a respondent's educational philosophy to be classified as essentialism, perennialism, progressivism, social reconstructionism, or existentialism based on Likert responses to 25 questions. Minor alterations to the survey items were made to produce an instrument appropriate for dissemination to graduate students in higher education. For example, all instances of "teacher" were replaced with "instructor."

Supplementary questions were also devised to supplement the Educational Philosophy Inventory. Specifically, students were asked to provide background on their previous disciplinary affiliations, formal teaching and learning training, and future career goals. In addition, questions were crafted to prompt participants to reflect not only on their own philosophy of education, but 
also on the philosophies that they had actually experienced. A summary of the five educational philosophies (Table 1) was provided to respondents to aid them in considering the extent to which each philosophy was enacted during their undergraduate and graduate educations. Responses were used to gauge the importance of one's own educational experiences on developing one's educational philosophy. Each participant was also asked to reflect on the philosophy that he or she currently applies in the classroom, as well as the philosophy that they would like to employ in the future. Responses were used to infer whether or not graduate students are currently enacting their espoused philosophy, or whether further educational training is needed to help them meet their goals. The design of supplemental questions was guided by principles developed by survey research experts ${ }^{16,17,18}$.

The Philosophy of Education Survey, including the Educational Philosophy Instrument and supplemental questions described above, was reviewed by a number of parties to ensure validity. First, a draft was piloted with a group of eight engineering students and faculty, and minor suggestions were addressed. The final version was reviewed by the Institutional Review Board and Office of Assessment at the Georgia Institute of Technology, as suggested by previous authors $^{19,20}$. A final copy of the survey is available in Appendix A.

\section{Survey Administration}

The Philosophy of Education Survey was administered during the Spring 2012 semester to graduate students at the Georgia Institute of Technology (Georgia Tech). Graduate students from aerospace engineering, civil engineering, environmental engineering, mechanical engineering, digital media, psychology, and management were invited to participate via email in an online version of the survey hosted by Survey Monkey. Overall, 291 graduate students completed the survey, which was defined as the completion of at least all 25 items on the Educational Philosophy Inventory.

\section{Survey Analysis}

Several statistical methods were used to analyze survey data. For the Educational Philosophies Inventory, responses (on a 1-5 scale) for essentialist, perennialist, progressivist, social reconstructionist, and existentialist questions were added together, as per Sadker and Zittleman ${ }^{9}$. A student's philosophy of education was designated as the philosophy receiving the highest total score. Data resulting from remaining supplemental questions asking students to reflect on their undergraduate and graduate classroom experiences, as well as their own current and future teaching practices (Appendix A), were first converted from a five-point scale to binary scores. Students indicating responses of 1-3 or alternative responses (no teaching experience or don't plan to teach) were assigned a score of " 0 ", representing that they did not experience or support the philosophy. Students indicating a 4-5 were assigned a "1" to represent that their experiences related to or their conceptions supported the given philosophy. Pearson's chi-squared tests were then used to compare the proportion of students experiencing each philosophy in their undergraduate versus graduate careers. Similarly, chi-square tests were used to compare the number of students endorsing each philosophy in their current versus future teaching practices. 


\section{Results}

An investigation was conducted to explore graduate students' philosophies of education at Georgia Tech. Student responses to the Philosophy of Education Survey were used to characterize graduate student backgrounds, determine the dominant philosophies of graduate students based on the Educational Philosophy Inventory, as well as examine graduate students' reflections on their experienced, enacted, and espoused philosophies.

\section{Respondent Demographics, Prior Experiences, and Future Career Goals}

A diverse population of graduate students elected to complete the Educational Philosophy Survey. Of the 291 respondents, $60.8 \%$ were male, $76.9 \%$ were US citizens, and $83.0 \%$ were majoring in a technical field (engineering, computing, or science). In addition, a majority of participants were pursuing a $\mathrm{PhD}(63.2 \%)$, while others were planning on enrolling in a $\mathrm{PhD}$ program in the future $(12.4 \%)$ (Table 2$)$.

In addition to training in their respective fields of study, some students also reported prior experiences to aid in molding them into effective instructors. While $67.4 \%$ of students reported completing no formal instruction on how to teach, $17.5 \%$ and $10.3 \%$ indicated that they had completed a course at Georgia Tech or another institution, respectively. Beyond educationrelated coursework, 53.3\% engaged in an authentic teaching experience as TA, which included grading papers (50.9\%), holding office hours (40.2\%), and actually teaching (35.4\%). Some students even participated in more demanding teaching experiences, such as independently designing and teaching a course $(9.6 \%)$, disseminating a departmentally-created course $(9.6 \%)$, or co-teaching a course with a mentor (11.7\%) (Table 3$)$.

Students' future career and teaching goals were varied. Most students indicated a desire to enter industry (51.2\%), while others showed interests in pursuing academic careers at doctoral/research institutions (29.3\%) or starting government careers (12.9\%). Although only a minority of respondents actually wanted to teach $(38.8 \%)$, most respondents noted a preference toward teaching undergraduate $(57 \%)$ or graduate $(48.5 \%)$ students (Table 4$)$. 
Table 2. Demographics of graduate students completing the Educational Philosophy Survey.

\begin{tabular}{|lc|}
\hline Demographic & Percentage (\%) \\
\hline Gender $(n=291)$ & \\
\hline Male & 60.8 \\
Female & 39.2 \\
\hline Citizenship $(n=290)$ & 76.9 \\
\hline US Citizen & 1.7 \\
Permanent Resident & 21.4 \\
International & \\
\hline Graduate Major $(n=289)$ & 83.0 \\
\hline Engineering, computing, or science & 17.0 \\
\hline Non-technical & \\
\hline Degree Status $(n=291)$ & 63.2 \\
\hline Currently pursuing PhD & 12.4 \\
Planning to purse a PhD & 24.4 \\
\hline Never planning to purse a PhD & \\
\hline
\end{tabular}

Table 3. Graduate students' self-reported teaching-related training ${ }^{\mathrm{a}}$.

\begin{tabular}{|lc|}
\hline Teaching-Related Training & Percentage (\%) \\
\hline Formal Instruction $(n=291)$ & 67.4 \\
\hline Completed no formal instruction on how to teach a class & 17.5 \\
Completed a course on teaching/learning at Georgia Tech & 14.4 \\
Completed a departmental teaching practicum & 10.3 \\
Completed related coursework at another institution & 53.3 \\
\hline Practical Teaching Experience $(n=291)$ & 28.5 \\
\hline Served as a TA for a course & 11.7 \\
Served as a guest lecturer (or substitute) & 9.6 \\
Co-taught a course (with a faculty or mentor instructor) & 9.6 \\
Had full responsibility for a course (designing, teaching, grading) & 50.9 \\
Independently taught a departmentally designed course (teaching, grading) & 40.2 \\
\hline Teaching Assistant Experience $(n=291)$ & 35.4 \\
\hline Grading papers & \\
Holding office hours & \\
Teaching & \\
\hline
\end{tabular}

${ }^{a}$ Note: Percentages for each training type (formal instruction, practical teaching experience, and teaching assistant experience) do not add to $100 \%$. Students were able to select more than one entry within each training type. 
Table 4. Graduate students' self-reported future career and teaching goals.

\begin{tabular}{|lc|}
\hline Teaching-Related Training & Percentage (\%) \\
\hline Future Career Goals $(n=287)$ & 51.2 \\
\hline Industry career & 29.3 \\
Academic career at a doctoral/research institution & 12.9 \\
Government career & 3.1 \\
Academic career at a master's college/university & 2.8 \\
Academic career at a baccalaureate college & 0.3 \\
Academic career at a 2-year college & 0.3 \\
Academic career at a K-12 level & \\
\hline Teaching Goals ${ }^{\text {a }}(n=291)$ & 38.8 \\
\hline Want to teach as part of career & 57.0 \\
Want to teach undergraduate students & 48.5 \\
Want to teach graduate students & 22.3 \\
Want to teach K12 students & \\
\hline
\end{tabular}

${ }^{a}$ Note: Percentages for teaching goals category do not add to $100 \%$. Students were able to select more than one entry.

\section{Respondents' Responses to the Educational Philosophies Inventory}

As part of completing the survey, respondents answered the 25-item Educational Philosophies Inventory designed to capture their philosophies of education. Student responses to these items most reflected endorsement of an essentialist or progressivist philosophy, although some students' responses were more characteristic of social reconstructionist, perennialist or existentialist philosophies.

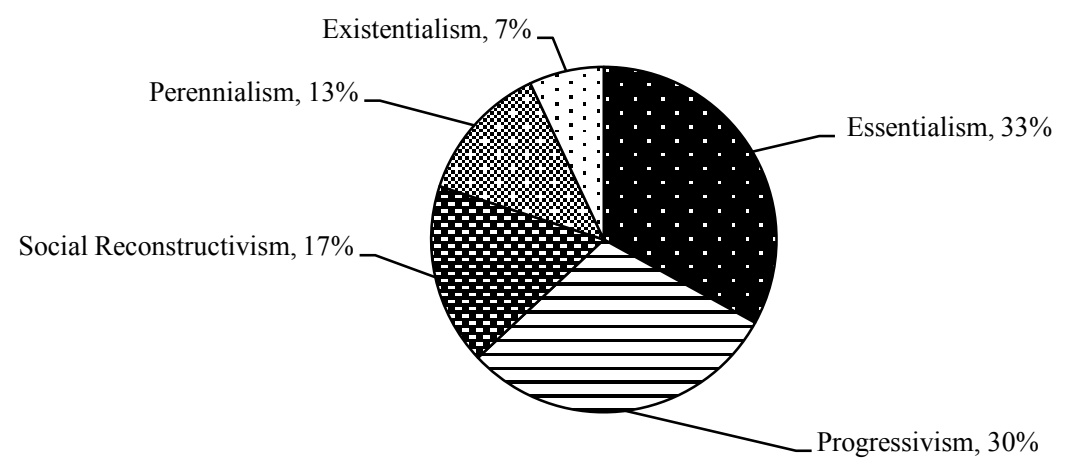

Figure 1: Educational Philosophies of Graduate Student Sample

\section{Respondents' Perceptions of their Philosophies of Education}

In addition to answering the Educational Philosophies Inventory items, students also reviewed basic definitions of the five major philosophies to aid them in reflecting on their past and future teaching and learning experiences. Most students classified their undergraduate classrooms as essentialist (73.5\%), perennialist (43.3\%), or progressivist (42.3\%). Similarly, students' 
graduate educations were most characteristically progressivist (56.7), essentialist (54.0\%), and perennialist (46.4\%). When further comparing students' undergraduate and graduate educations, a higher proportion of students experiencing progressivist and existentialist classrooms statistically increased $(p \leq 0.001)$ from their undergraduate and graduate careers, while the number of students exposed to essentialist and social reconstructionist significantly decreased $(p$ $\leq 0.001)$. Thus, while the three dominant philosophies were identical for students' undergraduate and graduate educational experiences, some shifts in the philosophies which students saw enacted were detected (Table 5).

After reflecting on the philosophies that they themselves experienced, respondents were also asked to consider their own current and future teaching practices. Most students' current teaching practices reflected perennialism (30.2\%), essentialism (28.9\%), and progressivism (26.5\%), but ideally in the future they wanted their methods to also incorporate existentialism (39.2\%), in addition to perennialism (47.8\%) and essentialism (43.0\%). Further analysis shows that a higher proportion of students plan to apply each of the five educational philosophies in the future, as compared to the number that currently enact the philosophies $(p \leq 0.05)$. As a result, not only may students' predominant philosophies change in the future when they are instructors, but they may increase their application of all philosophy types (Table 6).

Table 5. Educational philosophies experienced by graduate students.

\begin{tabular}{|l|cccc|}
\hline \multirow{2}{*}{ Educational Philosophy } & \multicolumn{2}{c|}{$\begin{array}{c}\text { Respondents Reporting Evidence } \\
\text { of Philosophy in: }\end{array}$} & \multicolumn{2}{c|}{ Chi-Square Test } \\
\cline { 2 - 5 } & $\begin{array}{c}\text { Undergraduate } \\
\text { Education (\%) }\end{array}$ & $\begin{array}{c}\text { Graduate } \\
\text { Education (\%) }\end{array}$ & $\chi^{2}(1, N=291)$ & $p$ \\
\hline Essentialism & 73.5 & 54.0 & 24.16 & $\leq 0.001^{* * *}$ \\
Perennialism & 43.3 & 46.4 & 0.56 & 0.453 \\
Progressivism & 42.3 & 56.7 & 12.13 & $\leq 0.001^{* * *}$ \\
Social Reconstructionism & 21.3 & 11.3 & 10.58 & $\leq 0.001^{* * *}$ \\
Existentialism & 26.8 & 42.3 & 15.39 & $\leq 0.001^{* * *}$ \\
\hline
\end{tabular}

Table 6. Graduate students' enacted and espoused educational philosophies $(n=291)$.

\begin{tabular}{|l|cccc|}
\hline \multirow{2}{*}{ Educational Philosophy } & \multicolumn{2}{c|}{$\begin{array}{c}\text { Respondents Reporting Philosophy } \\
\text { Reflected in: }\end{array}$} & \multicolumn{2}{c|}{ Chi-Square Test } \\
\cline { 2 - 5 } & $\begin{array}{c}\text { Current Teaching } \\
\text { Practices (\%) }\end{array}$ & $\begin{array}{c}\text { Future Teaching } \\
\text { Practices (\%) }\end{array}$ & $\chi^{2}(1, N=291)$ & $p$ \\
\hline Essentialism & 28.9 & 43.0 & 12.55 & $\leq 0.001^{* * *}$ \\
Perennialism & 30.2 & 47.8 & 18.78 & $\leq 0.001^{* * *}$ \\
Progressivism & 26.5 & 35.4 & 5.44 & $0.020^{*}$ \\
Social Reconstructionism & 15.1 & 36.1 & 35.57 & $\leq 0.001^{* * *}$ \\
Existentialism & 20.6 & 39.2 & 23.91 & $\leq 0.001^{* * *}$ \\
\hline
\end{tabular}




\section{Discussion}

\section{Similarities between Educational Philosophies Inventory and Student Perceptions}

Several similarities exist between students' educational philosophies as indicated by the Educational Philosophies Inventory and their own reflections. For instance, according to the Inventory, most students were aligned with the essentialist or progressivist philosophies. Indeed, upon self-examination of their current teaching practices, a high percentage of students classified their current teaching methods as essentialist and progressivist. Interestingly, essentialism was among the philosophies that students most saw applied in both their own undergraduate and graduate classrooms. Also, significantly more students plan to apply essentialism- and progressivist-based teaching practices in the future, as compared to the number of students who currently enact such methods. Thus, the instructor-centered pedagogies stemming from an essentialist philosophy of education that were common in the past are also expected to predominate in the future for this sample of graduate students.

A few differences between Inventory and respondent reflection results were also identified. Namely, a high percentage of students report being exposed to perennialism in both their undergraduate and graduate educations. While the Inventory revealed few students to subscribe to a perennialist philosophy, student reflections indicate that perennialism is the philosophy that most students currently apply and would like to enact in the future. One possible explanation, supported by the work of McKenna and $\mathrm{Yalvac}^{6}$, may be that students are operating under a perennialist paradigm only because that is what they themselves have seen enacted in the classroom, not because they believe that perennialist pedagogies are the most advantageous. The Inventory also suggests that existentialism was the least endorsed philosophy, yet it is among the top three philosophies that students would like their future teaching practices to reflect. Only a few students reported experiencing this philosophy themselves as undergraduates, yet many students indicated that it was prevalent in their graduate level classes. Perhaps students would like to adopt this philosophy in the future because they have recognized the benefits of this student-centered philosophy in their own graduate educations.

\section{Instructor-Versus Learner-Centered Philosophies}

Regardless of the fact that the Inventory shows support for learner-centered pedagogies, student reflections suggest endorsement of instructor-centered pedagogies. Specifically, the inventory showed support for essentialism (instructor-centered) and progressivism (learner-centered). However, the highest proportion of students consistently rated perennialism and essentialism, both instructor-centered philosophies, as characteristic of both their current and future teaching practices. While it seems that instructor-centered pedagogies are likely to persist into the future of education (based on the current graduate student sample), there is evidence that learnercentered teaching strategies may also become more common. For instance, progressivism was in the top three highest-rated philosophies for students' current teaching practices, while existentialism was in the top three highest-ranked philosophies for students' future teaching 
practices. Overall, instructor-centered methods are expected to persist into the future, although there is potential for learner-centered pedagogies to also become more commonplace.

\section{Implications for Graduate Education}

The results of this preliminary student suggest that efforts are needed to educate graduate students, especially those interested in pursuing academic careers, about the relationships between educational philosophies and teaching and learning. Discrepancies between Inventory results and student perceptions (outlined above) demonstrate that students may not be aware of their own philosophies of education. While the inventory certainly illustrated that students support an essentialist philosophy (instructor-centered), it also showed almost equal support for progressivism (learning-centered). Perhaps if graduate students (i.e. future instructors) were aware about their espoused philosophy, and the documented benefits on student learning ${ }^{21}$, then they would be more adept to incorporating related pedagogies into to their current teaching and learning practices. Otherwise, graduate students may be left replicating those philosophies that they saw applied during their own undergraduate and graduate careers (perennialism and essentialism), as supported by McKenna and Yalvac ${ }^{6}$. Finally, it was observed that students indicated a desire to further incorporate existentialism into their teaching practices. Given that this philosophy was seldom demonstrated for graduate students during their own coursework, perhaps further instruction on related educational theories and pedagogies could be helpful.

\section{Conclusions and Future Work}

An investigation was conducted to explore the educational philosophies of graduate students, since many of these students will become the instructors of tomorrow. Graduate students at Georgia Tech $(n=291)$ were administered a survey that included the Educational Philosophies Inventory, as well as several supplemental questions. The following conclusions were made based on the results.

1. According to the Educational Philosophies Inventory, both instructor-centered (essentialism) and student-centered (progressivism) philosophies predominate among graduate students. However, students indicated instructor-centered philosophies (essentialism and perennialism) to be most characteristic of their current and future teaching practices.

2. While progressivism is strongly endorsed according to the Inventory, students indicated essentialism and perennialism, both characteristic of their own classroom experiences, to be reflected in their current and future teaching practices.

3. Discrepancies between Inventory and student reflection results suggest that interventions may be needed to educate graduate students about educational philosophies and related teaching and learning implications.

Current graduate student educational philosophies foreshadow the types of pedagogies that will be implemented in future engineering courses, given no formal teaching interventions. While each of the five educational philosophies is theoretically-based, some may be more appropriate for engineering education than others. For instance, emphasis of progressivists on problem 
solving may provide students with critical thinking skills necessary to become successful engineers, while perennialist approaches of lecture and discussion may teach students about fundamental concepts but leave them unequipped to solve complex problems. If graduate students prescribe to predominately traditional philosophies, then perhaps initiatives are needed to educate graduate students about more contemporary ones. By examining graduate student educational philosophies, research can provide important insights for ensuring the future quality of engineering education.

\section{Acknowledgment}

The authors would like to acknowledge Dr. Wendy Newstetter for her support during the IRB process and for introducing us to the instrument in her seminar course. Dr. Caroline Noyes, the Assistant Director of the GT Office of Assessment, was instrumental in refining supplementary survey questions. This material is based upon work supported by the National Science Foundation Graduate Research Fellowship under Grant No. DGE-0644493.

\section{References}

1. Knobloch, N. A., \& Ball, A. L. (2006). Analyzing the contextual, motivational, and conceptual characteristics of teaching faculty in regard to the use of learner centered approaches in teaching. Paper presented at the Annual Meeting of the American Education Research Association, San Francisco, CA.

2. Rando, W., \& Menges, R. (1991). How practice is shaped by personal theories. New Directions for Teaching and Learning, 45, 7-14.

3. Trigwell, K., Prosser, M., \& Waterhouse, F. (1999). Relations between teachers' approaches to teaching and students' approaches to learning. Higher Education 37(1), 57-70.

4. Jarvis-Selinger, S., Collins, J. B., \& Pratt, D. D. (2007). Do academic origins influence perspectives on teaching? Teacher Education Quarterly, 34(3).

5. Bieber, J. P., \& Worley, L. K. (2006). Conceptualizing the academic life: Graduate students' perspectives. The Journal of Higher Education, 77(6), 1009-1035.

6. McKenna, A., \& Yalvac, B. (2007). Characterizing engineering faculty's teaching approaches. Teaching in Higher Education, 77(6), 1009-1035.

7. Torres-Ayala, A. T. (2012). Future Engineering Professors' Conceptions of Learning engineering. (Dissertation), University of South Florida, Tampa, FL.

8. Saroyan, A., Dagenais, J., \& Zhou, Y. (2009). Graduate students' conceptions of university teaching and learning: Formation for change. Instructional Science, 37(6), 579-600.

9. Sadker, D. M., \& Zittleman, K. R. (2007). Teachers, Schools, and Society (8th ed.). Newy York, NY: McGrawHill higher Education.

10. Noddings, N. (2001). Philosophy of Education (3rd ed.). Boulder, CO: Westview Press.

11. Koch, J. (2007). So You Want to Be a Teacher?: Teaching and Learning in the 21st Century. Boston, MA: Houghton Mifflin Compnay.

12. Brannon, M. L. (2009). Preparing graduate students to teach: A seminar on teaching for graduate assistants in engineering. Paper presented at the American Society for Engineering Education Annual Conference and Exposition, Austin, TX.

13. Crede, E. D., \& Borrego, M. (2009). Preparing graduate engineering students for academia: Assessment of a teaching fellowship. Paper presented at the American Society for Engineering Education Annual Conference and Exposition, Austin, TX.

14. Newton, S., Soleil, L., Utschig, T., \& Llewellyn, D. (2010). Design and assessment of professional education development programming for graduate students at a research extensive university. Paper presented at the American Society for Engineering Education Annual Conference and Exposition, Louisville, KY. 
15. Winters, K. E., \& Matusovich, H. M. (2011). Graduate teaching assistants' decision making and perceptions of autonomy. Paper presented at the American Society for Engineering Education Annual Conference and Exposition, Vancouver, BC.

16. Weisberg, H. F., Krosnick, J. A., \& Bowen, B. D. (1996). An Introduction to Survey Research, Polling, and Data Analysis. Thousand Oaks, CA: Sage Publications Inc.

17. Alreck, P. L., \& Settle, R. B. (1995). The Survey Research Handbook (2nd ed.). Boston, MA: Irwin Professional Publishing.

18. Babbie, E. (1990). Survey Research Methods. Belmont, CA: Wadsworth, Inc.

19. Rogers, S. W., \& Goktas, R. K. (2010). Exploring engineering graduate student research proficiency with student surveys. 99(3), 263-278.

20. St. Clair, S., \& Baker, N. (2003). Faculty use and impressions of coursework management tools: A national survey. Journal of Engineering Education(2), 123-131.

21. Prince, M. (2004). Does Active Learning Work? A Review of the Research. Journal of Engineering Education, 93(3), 223-231. 


\section{Appendix A: Educational Philosophy Questionnaire (Originally 7 Separate Pages)}

1. Do you agree for your responses to be used for research purposes? yes no

2. Demographics
A. Gender:
Male
Female
B. Citizenship: US Citizen
Permanent Resident International (country):
C. Undergraduate institution:
D. Undergraduate degree (s) and in what year:

3. Describe your academic career at Georgia Tech.

A. Academic major:

B. Are you currently a PhD student:

${ }_{\mathrm{PhD}} \mathrm{P}^{\mathrm{Yes}} \mathrm{Yes}^{\mathrm{No}} \mathrm{No}^{\mathrm{No}}$

C. Number of years in graduate school at Georgia Tech:

D. Describe any formal instruction you have received on how to teach a class (check all that apply): Course on teaching/learning Coursework at previous institution GT departmental teaching practicum Other (please specify):

E. Have you ever (check all that apply): had full responsibility for a course (designing, teaching, grading)

_ independently taught a departmentally designed course (teaching, grading)

_ co-taught a course (taught with a faculty or mentor instructor)

_ served as a TA for a course

_

F. If you have served as a TA, what were your responsibilities (check all that apply)?

Holding office hours

Grading papers

Teaching

Other:

4. What kind of career are you seeking? Academic career at a doctoral/research institution

_ Academic career at a master's college/university Academic career at a baccalaureate college Academic career at a 2-year college

Academic career at K-12 level

Industry career

Government career

Other career:

5. As part of your career, do you want to teach?
Yes No

If so, what level of students would you like to teach? (check all that apply)

$\mathrm{K}-12$ Undergraduate Graduate Other

None 
6. Read the following statements ${ }^{\mathrm{a}}$. Indicate the extent to which you agree or disagree with each statement.

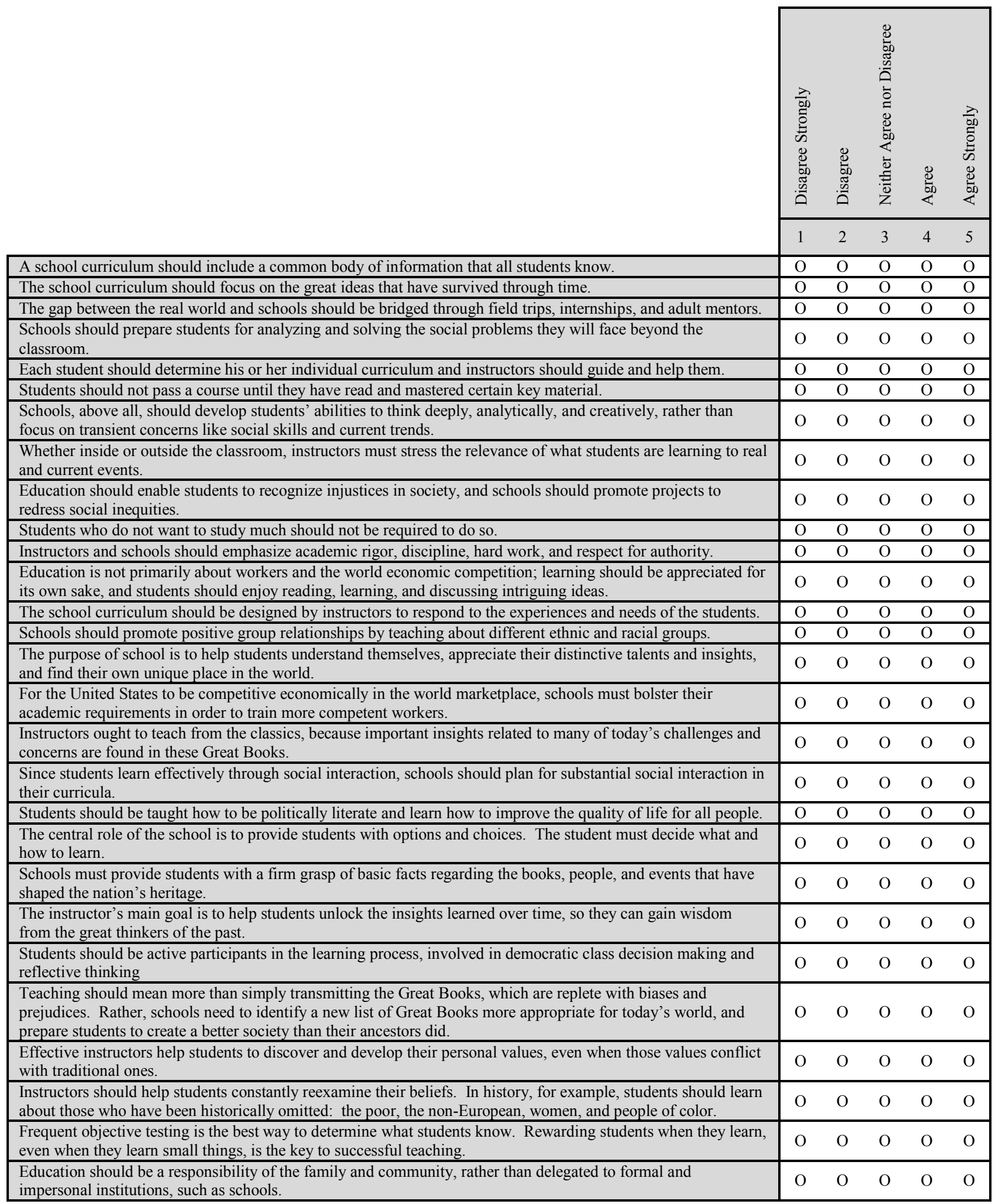

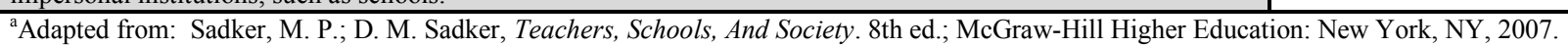


7. There are 5 major educational philosophies. Review the focus of study and the role of the instructor for each philosophy ${ }^{\mathrm{a}}$.

A. To what extent were the 5 educational philosophies reflected in your undergraduate education?

B. To what extent were the 5 educational philosophies reflected in your graduate education at Georgia Tech?

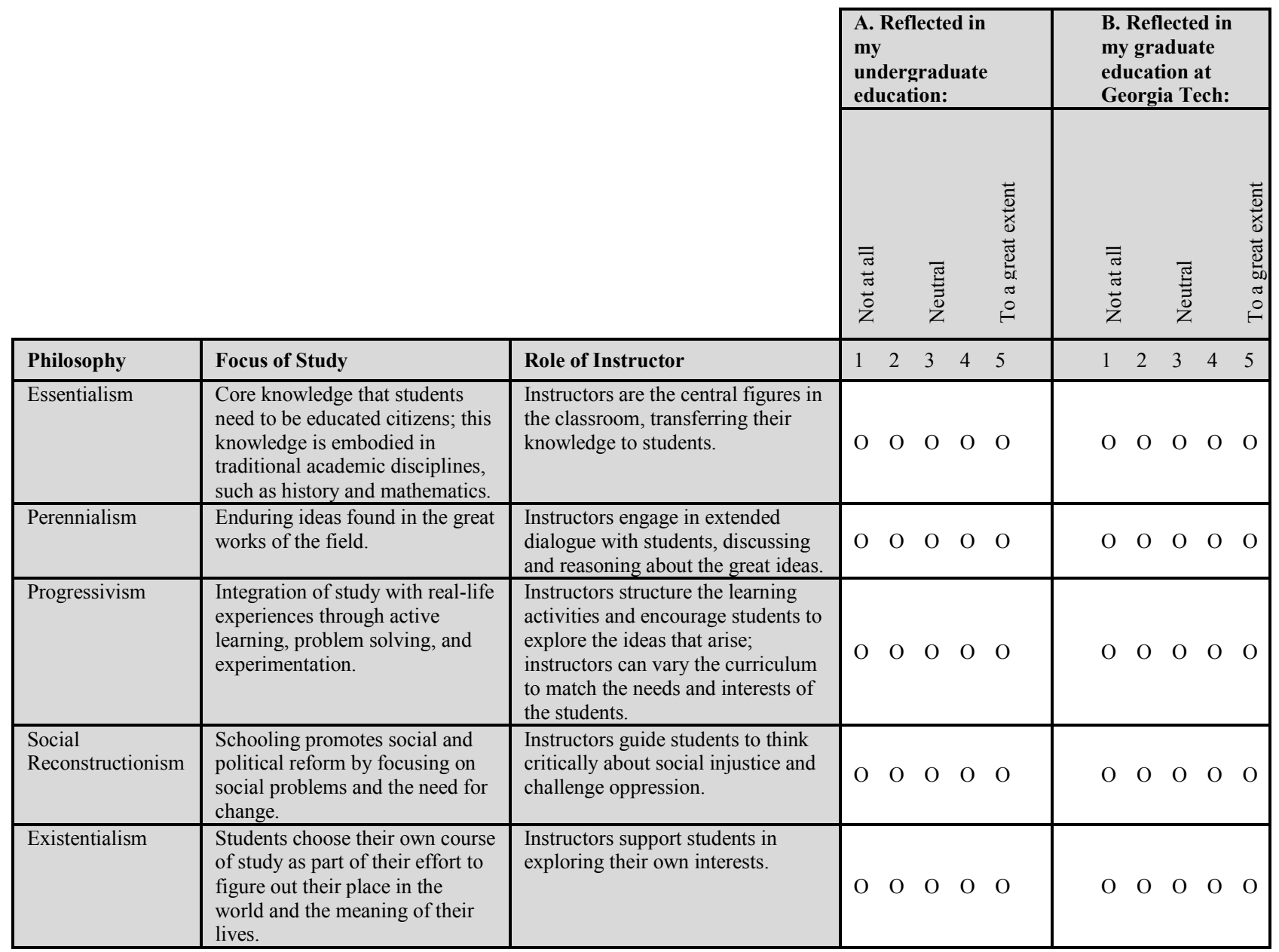

${ }^{\mathrm{a}}$ Adapted from: Koch, J., So You Want to Be a Teacher?: Teaching and Learning in the 21st Century. Houghton Mifflin Company: Boston, MA, 2007. 
8. There are 5 major educational philosophies. Review the focus of study and the role of the instructor for each philosophy ${ }^{\mathrm{a}}$.

A. To what extent are the 5 educational philosophies reflected in your current teaching practices?

B. To what extent would the 5 educational philosophies be ideally reflected in your future teaching practices?

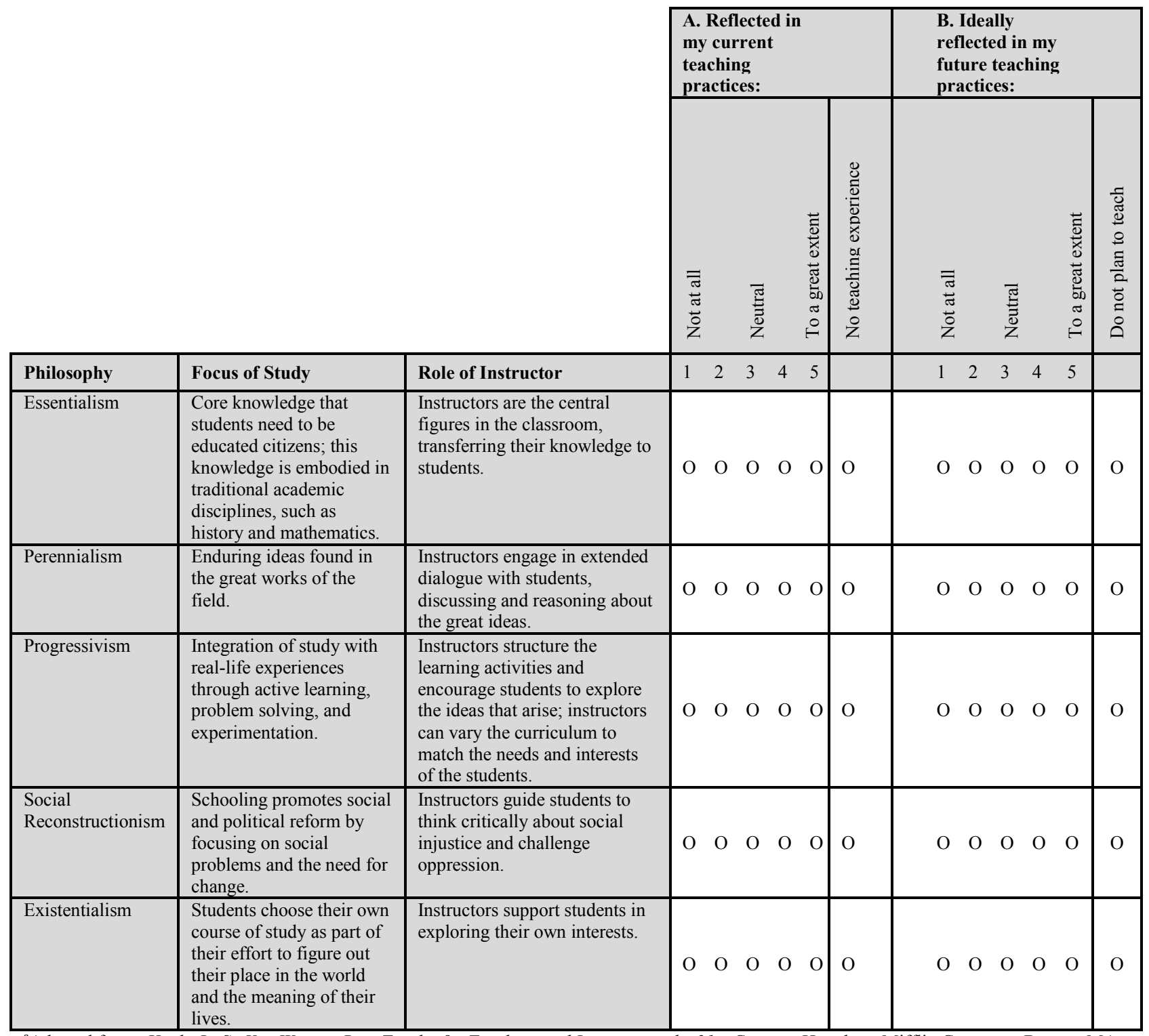

${ }^{\text {a} A d a p t e d ~ f r o m: ~ K o c h, ~ J ., ~ S o ~ Y o u ~ W a n t ~ t o ~ B e ~ a ~ T e a c h e r ?: ~ T e a c h i n g ~ a n d ~ L e a r n i n g ~ i n ~ t h e ~ 21 s t ~ C e n t u r y . ~ H o u g h t o n ~ M i f f l i n ~ C o m p a n y: ~ B o s t o n, ~ M A, ~}$ 2007.

9. Do you have any additional thoughts on how philosophies of education impact students' educational experiences?

10. Describe your most memorable educational experience. Which educational philosophy did it reflect? 